\title{
Documentation of the U.S. Geological Survey Sea Floor Stress and Sediment Mobility Database
}

Open-File Report 2012-1137

Version 1.1, May 2015 



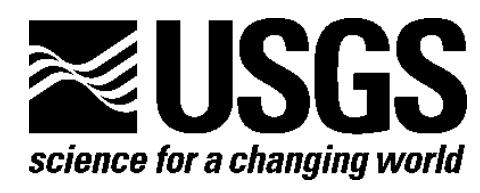

\section{Documentation of the U.S. Geological Survey Sea Floor Stress and Sediment Mobility Database}

By P. Soupy Dalyander, Bradford Butman, Christopher R. Sherwood, and Richard P. Signell

Open-File Report 2012-1137

Version 1.1, May 2015

U.S. Department of the Interior

U.S. Geological Survey 


\title{
U.S. Department of the Interior KEN SALAZAR, Secretary
}

\section{U.S. Geological Survey Marcia K. McNutt, Director}

U.S. Geological Survey, Reston, Virginia

First release: 2012, online

Revised: May 2015 (ver. 1.1), online

For more information on the USGS—-the Federal source for science about the Earth, its natural and living resources, natural hazards, and the environment-visit http://www.usgs.gov or call 1-888-ASK-USGS

For an overview of USGS information products, including maps, imagery, and publications, visit http://www.usgs.gov/pubprod

To order this and other USGS information products, visit http://store.usgs.gov

\begin{abstract}
Suggested citation:
Dalyander, P.S., Butman, Bradford, Sherwood, C.R., and Signell, R.P., 2015, Documentation of the U.S. Geological Survey Stress and Sediment Mobility Database (ver. 1.1, May 2015): U.S. Geological Survey Open-File Report 2012-1137, 20 p., at http://pubs.usgs.gov/of/2012/1137/.
\end{abstract}

Any use of trade, product, or firm names is for descriptive purposes only and does not imply endorsement by the U.S. Government.

Although this report is in the public domain, permission must be secured from the individual copyright owners to reproduce any copyrighted material contained within this report. 


\section{Contents}

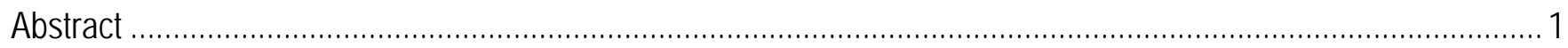

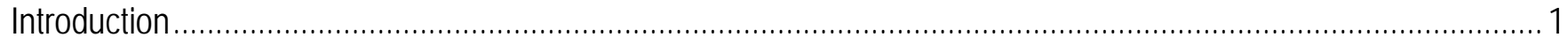

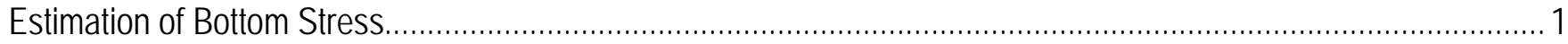

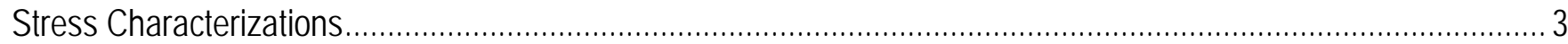

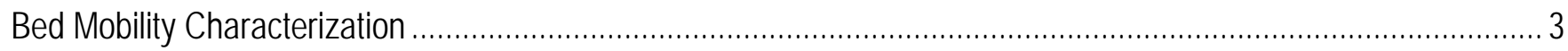

Contents of the Sea Floor Stress and Sediment Mobility Database ..................................................... 5

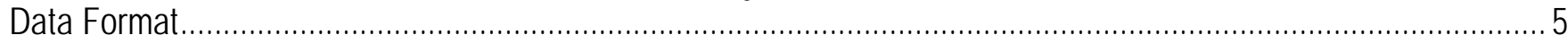

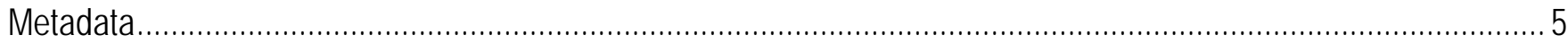

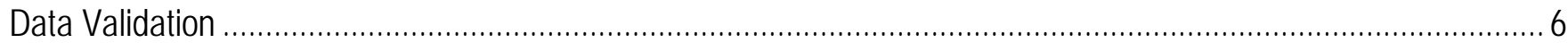

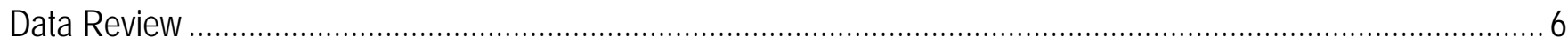

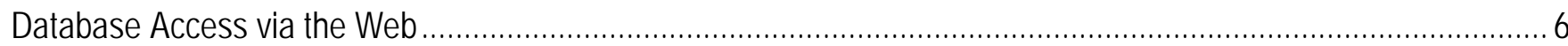

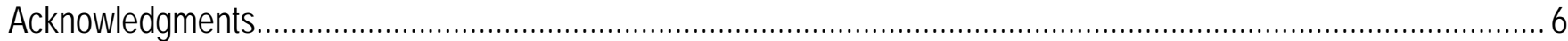

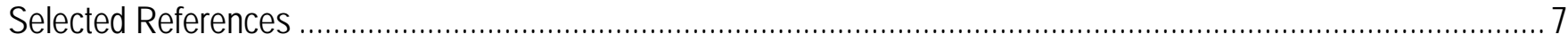

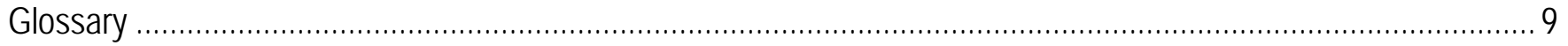

\section{Tables}

1. Example statistics included in the U.S. Geological Survey Sea Floor Stress and Sediment Sediment Mobility Database. 


\section{Conversion Factors}

SI to Inch/Pound

\begin{tabular}{lcc}
\hline \multicolumn{1}{c}{ Multiply } & To obtain \\
\hline meter $(\mathrm{m})$ & Length & \\
\hline & 3.281 & foot $(\mathrm{ft})$ \\
\hline meter per second squared $\left(\mathrm{m} / \mathrm{s}^{2}\right)$ & Acceleration & \\
\hline & 3.281 & foot per second squared $\left(\mathrm{ft} / \mathrm{s}^{2}\right)$ \\
\hline meters squared per second $\left(\mathrm{m}^{2} / \mathrm{s}\right)$ & Kinematic viscosity & \\
\hline & 10.765 & feet squared per second $\left(\mathrm{ft}^{2} / \mathrm{s}\right)$ \\
\hline kilopascal $(\mathrm{kPa})$ & Pressure & \\
\hline & 20.88 & pound per square foot $\left(\mathrm{lb} / \mathrm{ft}^{2}\right)$ \\
\hline kilogram per cubic meter $\left(\mathrm{kg} / \mathrm{m}^{3}\right)$ & Density & \\
\hline
\end{tabular}




\title{
Documentation of the U.S. Geological Survey Sea Floor Stress and Sediment Mobility Database
}

\author{
By P. Soupy Dalyander, Bradford Butman, Christopher R. Sherwood, and Richard P. Signell
}

\begin{abstract}
The U.S. Geological Survey Sea Floor Stress and Sediment Mobility Database contains estimates of bottom stress and sediment mobility for the U.S. continental shelf. This U.S. Geological Survey database provides information that is needed to characterize sea floor ecosystems and evaluate areas for human use. The estimates contained in the database are designed to spatially and seasonally resolve the general characteristics of bottom stress over the U.S. continental shelf and to estimate sea floor mobility by comparing critical stress thresholds based on observed sediment texture data to the modeled stress. This report describes the methods used to make the bottom stress and mobility estimates, statistics used to characterize stress and mobility, data validation procedures, and the metadata for each dataset and provides information on how to access the database online.
\end{abstract}

\section{Introduction}

Ocean waves and currents create bottom shear stress, a force at the seabed that influences physical, geological, and biological processes and thus is important in evaluating sites for offshore structures, understanding the distribution of toxic materials, and predicting the distribution of seabed plants and animals. The growing requirement for shear stress information across broad planning regions on the U.S. continental shelf cannot be met by direct measurements of bottom shear stress, which are expensive. Instead, wave and current output from numerical models can be used in a bottom boundary layer model to produce estimates of bottom stress across the continental shelf. These estimates are used to create the U.S. Geological Survey (USGS) Sea Floor Stress and Sediment Mobility Database, which contains statistical characterizations of bottom stress and sediment mobility for the U.S. continental shelf.

This report describes the methods used to make the bottom stress and mobility estimates, statistics used to characterize stress and mobility, data validation procedures, and the metadata for each dataset and provides instructions on how to access the data from the online database. Estimates of bottom stress and mobility will be added to the online database as they are developed.

\section{Estimation of Bottom Stress}

Bottom shear stress estimates are made following the Grant-Madsen (GM) model (Madsen, 1994), with bottom orbital velocity and bottom wave periods generated with third generation wave models (such as Simulation WAves Nearshore, SWAN; Holthuijsen and others, 1993) and near-bed current estimates from three-dimensional spatially and temporally resolved hydrodynamic models (such as the Regional Ocean Modeling System, ROMS; Shchepetkin and McWilliams, 2005). The bottom stress estimates are provided on a kilometer-scale grid matching the grid of the hydrodynamic model. 
The GM approach relies on an eddy viscosity turbulence closure model and formulates the wave stress ( $\left.\tau_{\text {wave }}\right)$, current stress $\left(\tau_{\text {curr }}\right)$, and combined wave-current bottom stress $\left(\tau_{\mathrm{wc}}\right)$ as functions of a representative bottom wave orbital velocity $\left(\mathrm{u}_{\mathrm{br}}\right)$, representative bottom wave period $\left(\mathrm{T}_{\mathrm{br}}\right)$, current flow at some reference height, the angle between wave and current propagation, and bottom roughness $\left(\mathrm{k}_{\mathrm{b}}\right)$. Full details of the GM formulation may be found in Glenn (1983), Grant and Madsen (1979, 1982, 1986), Glenn and Grant (1987), Madsen and others (1988), and Madsen (1994).

Wave direction, bottom orbital velocities, and bottom periods are calculated internally by the wave model. Near-bed current magnitude and direction are taken from the hydrodynamic model, with the reference height $\left(\mathrm{z}_{\mathrm{R}}\right)$ taken as the distance from the cell vertical midpoint to the seabed. The GM model requires that the current velocity be taken above the wave boundary layer (WBL) but within the log-profile current velocity layer. If the thickness of the WBL $\left(\delta_{\mathrm{w}}\right)$ calculated using the GM model exceeds the $z_{R}$ of one or more of the deepest grid cells, then the current estimate and associated reference height are used from the deepest grid cell at each location where zR exceeds $\delta_{\mathrm{w}}$. An estimate must be used for the maximum reference height where the log-profile velocity layer assumption is valid. As discussed in Grant and Madsen (1986), the thickness of the log-profile layer based on laboratory experiments is approximately 10 percent of the current boundary layer thickness (Clauser, 1956). Because tidal currents, storm currents, and mean flow have a boundary layer thickness on the order of a magnitude of tens of meters (Goud, 1987), a maximum value for $z_{R}$ is set as 5 meters (m). This value may overestimate the thickness of the log layer in some flow conditions; in-situ measurements of the near-bed profile have found some deviation from a log-profile at distances less than $5 \mathrm{~m}$ off the bed (Sanford and Lien, 1999).

The GM bottom boundary layer model also requires a value for bottom roughness; a uniform value of $0.005 \mathrm{~m}$ is used throughout the domain. The physical roughness used in stress calculations is the Nikuradse sand grain size ( $\mathrm{k}_{\mathrm{b}}$, a measurement of roughness), which includes contributions from bedform microtopography (Nikuradse, 1933; Madsen, 1994). However, even if sediment grain size were an adequate proxy for bottom roughness and grain size data at kilometer-scale were available, defining a single roughness for each grid cell would be nonphysical in many regions because of finer scale spatial variability in sediment texture (Churchill and others, 1994). Bedform microtopography also exhibits finer scale spatial variability as well as time variability that includes a dependence on bottom stress. When the critical stress of motion is exceeded on a sandy seabed, ripples will start to form, which enhance the roughness (Glenn, 1983; Glenn and Grant, 1987). Ripple characteristics vary with flow conditions, with ripples steepening under increased bottom orbital velocities until the "breakoff region" is entered and ripples begin to be smoothed out or destroyed (Grant and Madsen, 1986). Accounting for these processes is difficult because the seabed may not be in equilibrium with flow conditions due to relic bedforms. Bedforms may also be formed or destroyed through bioturbation or anthropogenic activity, such as trawling. During nonstorm conditions, particularly in muddy sediments, biological activity can influence or dominate the microtopography (Grant and Madsen, 1986). In addition, nongeological elements, such as shell hash or submerged aquatic vegetation (SAV), will influence the roughness. There is also a contribution of sediment being transported near the seabed to the total bottom roughness (Glenn, 1983), which itself is difficult to compute due to the influence of stress history on sediment resuspension (for example, bed armoring) and sediment advection from other locations. Over smaller study areas, these problems may be addressed through direct observation and estimation of the bottom roughness (Lyne and others, 1990a,b). Use of a uniform value of $0.005 \mathrm{~m}$ most likely underestimates the roughness and hence the stress for sandy seabeds during moderate storm conditions when ripples develop, but based on sea floor observations (Grant and Madsen, 1986; Lyne and others, $1990 \mathrm{a}, \mathrm{b})$ is a reasonable estimate during more extreme storms when ripples flatten, during quiescent 
periods if relict bedforms are absent, and over muddy seabeds where ripples do not form. Additional influences of biological and anthropogenic forces on roughness are difficult to spatially or temporally resolve. Use of a uniform value of $0.005 \mathrm{~m}$ for bottom roughness produces a small relative error in the calculated stress, which varies with the natural logarithm of $\mathrm{k}_{\mathrm{b}}$ (Madsen and others, 1993).

\section{Stress Characterizations}

Stress characterizations are resolved for each model grid cell both annually and seasonally, for example, winter (December-February), spring (March-May), summer (June-August), and fall (September-November). Where time series of bottom stress longer than a year are available, estimates of interannual variability are also provided.

The baseline set of statistics used to characterize stress spatially and temporally include (Table 1):

- Median: the value for which 50 percent of stress estimates fall below and 50 percent of stress estimates fall above (equivalent to the mean for a normal distribution)

- Half interpercentile range: half of the difference between the 84th and 16th percentiles (equivalent to the standard deviation for a normal distribution)

- $\quad$ 95th percentile: the value exceeded by 5 percent of data in the time series (for example, 95 percent of output points are less than this value)

\section{Bed Mobility Characterization}

Bed mobility is assessed at discrete locations by comparing bottom stress to grain-size specific critical stress thresholds established using observed surficial sediment texture point measurements. Bed mobility is established as the percentage of time the critical stress at the location of each sample is exceeded for that sample; a yearly bed mobility of 20 percent would indicate the bed is mobilized 20 percent of the year. While bed mobility occurrence defined in this manner indicates the overall potential for sediment movement throughout the year, it does not characterize the frequency of mobility (for example, a mobility of 25 percent could indicate a 6 hour daily disturbance, or 100 percent disturbance over 3 months of the year). To characterize frequency, the recurrence interval of mobility events (in units of days between events) is calculated for the winter and summer as the total length of the time series (in days) divided by the number of events within the time period. A recurrence interval of 10 days, for example, would indicate that, on average, the bed is mobilized every 10 days. The bed mobility statistics are therefore (Table 1):

- Bed mobility percentage: percentage of time the critical stress threshold is exceeded at each location

- Bed mobility recurrence interval: total number of mobility events divided by the total length of the time series, in days

The total bottom stress as calculated previously is an estimate of the total force in the bottom boundary layer, based on a uniform roughness value of $0.005 \mathrm{~m}$ that includes a bedform contribution to roughness. Seawater in the bottom boundary layer responds to stress resulting from both the form drag of microtopography as well as the skin friction of the sediment boundary, but seafloor sediment only responds to the skin friction. Use of the total bottom boundary layer stress would overestimate the force acting on the sand grains to potentially induce resuspension and transport (Zhenlin Li, 1994). At each discrete location where sediment data were available, bottom stress was recalculated from wave and circulation model output using the GM method and a roughness $\left(\mathrm{k}_{\mathrm{b}}\right)$ based on the grain size distribution at that location. While there are other methodologies that allow the skin friction to be partitioned from total boundary layer stress (see Churchill and others, 1994), in this case, the total boundary layer stress 
is based on an assumed rather than an observed bedform roughness, and partitioning would therefore not improve the estimate of the skin friction compared with basing the roughness on the sediment grain size distribution.

The texture data include the distribution of sediment over grain size classes ranging from -5 to 11 phi $(\phi)$, ranging from gravel through sand and silt to clay. For sand grains, there is an established positive correlation between critical stress and sediment grain size (Soulsby, 1997). However, mixed beds with a high fraction of fine-grained sediments act cohesively, increasing the critical stress (Panagiotopoulos and others, 1997; Torfs and others, 2000; van Ledden and others, 2004). Texture observations are therefore classified as cohesive or noncohesive based on the fraction of clay; if the clay fraction exceeds 7.5 percent, then the sediment is deemed cohesive; if less than or equal to 7.5 percent, then the sediment is noncohesive. This classification was based on the mean value from laboratory testing that indicates the threshold to develop cohesive properties is between 5 and 10 percent clay (van Ledden and others, 2004).

Critical stress thresholds $\left(\tau_{c r}\right)$ for noncohesive sediment mixtures are calculated from the critical Shields parameter $\left(\theta_{c r}\right)$, gravity $\left(g, 9.81\right.$ meters per second squared $\left.\left(\mathrm{m} / \mathrm{s}^{2}\right)\right)$, the density of sediment $(\rho s$, taken as 2,650 kilograms per cubic meter $\left.\left(\mathrm{kg} / \mathrm{m}^{3}\right)\right)$, the density of seawater $\left(\rho\right.$, taken as $\left.1,027 \mathrm{~kg} / \mathrm{m}^{3}\right)$, and the median grain size $\left(d_{50}\right)$ following Soulsby (1997) as

$$
\tau_{c r}=\theta_{c r} \cdot\left(\rho_{s}-\rho\right) d_{50}
$$

The critical Shields parameter is calculated from a dimensionless sediment parameter, $D^{*}$, as

$$
\theta_{c r}=\frac{0.30}{1+1.2 D^{*}}+0.055\left[1-\exp \left(-0.020 D^{*}\right)\right]
$$

with $D^{*}$ defined from the kinematic viscosity ( $v$, taken as $1.36 \times 10^{-6}$ meters squared per second $\left(\mathrm{m}^{2} / \mathrm{s}\right)$ ) as

$$
D^{*}=d_{50}\left(\frac{\Delta g}{v^{2}}\right)^{\frac{1}{3}}
$$

The roughness used in calculating bottom stress at locations with a noncohesive sediment distribution was also set to $d_{50}$.

For cohesive beds, the critical stress threshold is more difficult to establish. Particle cohesion strength, and hence critical stress, varies with fluid properties, such as salinity and temperature; sediment matrix properties, including the texture distribution, chemical composition, and water content; and biological influences, such as pelletization, organic content, and bioturbidity (Dickhudt and others, 2011). Furthermore, as the bed erodes, the critical shear stress may increase (for example, bed armoring) as older sediment layers with different properties are exposed (van Ledden and others, 2004). Because, at present, data do not exist to support a more complex model of critical stress as a function of these varying properties, a single value is used for all samples identified as cohesive. In-situ, ex-situ, and laboratory experimental measurements of critical stress in mixed beds range from 0.01 to $0.7 \mathrm{pascal}(\mathrm{Pa})$ (see Dickhudt and others, 2011, for a review). Because the primary interest of this study is initiation of bed mobility, a value of $0.1 \mathrm{~Pa}$ is chosen. The roughness used in the skin friction calculation for cohesive sediments was set to 62.5 micrometers ( $\mu \mathrm{m} ; 4 \phi$, the boundary between very fine sand and coarse silt), which has a critical stress based on Soulsby (1997) of $0.1 \mathrm{~Pa}$. Since different values may be appropriate for different regions, the threshold value for cohesive sediments is included in the metadata for each set. 


\section{Contents of the Sea Floor Stress and Sediment Mobility Database}

The USGS Sea Floor Stress and Sediment Mobility Database consists of a set of statistics that spatially and temporally characterize stress and bed mobility (table 1). Analysis suggests that the available models provide reasonable statistics but that individual stress events are not well-resolved. Statistics of bottom stress and mobility are therefore included in the database, but the time series of bottom stress used to develop these statistics are not.

Table 1. Example statistics included in the U.S. Geological Survey Sea Floor Stress and Sediment Sediment Mobility Database.

[See "Stress Characterizations" and "Bed Mobility Characterizations" sections in this report for more complete descriptions of how each statistic is computed from bottom stress]

Statistics Describing Spatial and Temporal Variability of Bottom Stress

Median: the value for which 50 percent of stress estimates fall below and 50 percent of stress estimates fall above (equivalent to the mean for a normal distribution)

Half interpercentile range: half of the difference between the 84th and 16th percentiles (equivalent to the standard deviation for a normal distribution)

95th percentile: the value exceeded by 5 percent of data in the time series (for example, 95 percent of output points are less than this value)

Statistics Describing Bed Mobility

Bed mobility percentage: percentage of time the critical stress threshold is exceeded at each location

Bed mobility recurrence interval: total number of mobility events divided by the total length of the time series, in days

Other statistics of the bottom stress and mobility time series may be developed and included in the database.

\section{Data Format}

Bottom stress and sea floor mobility statistics in the database are provided in ArcGIS shapefile format. Bottom stress statistics are provided in polygon format, with each polygon corresponding to a grid cell in the underlying numerical model. One shapefile is provided for each bottom stress statistic, with each file containing five attributes corresponding to the value calculated on the year and by season (winter, spring, summer, and fall). Sea floor mobility statistics are provided in point format, with each point corresponding to one sediment texture measurement.

\section{Metadata}

Fedeal Geographic Data Committee metadata are provided with each shapefile describing the underlying hydrodynamic and wave models, which vary by geographic region, used to generate the statistics contained within that file. The metadata include the types of numerical models used, the model spatial and temporal resolution, input data used, the time period over which output was calculated, and specific model parameters that would be necessary to recreate the results. The source of the sediment texture data used for generating critical stress values in the calculation of sea floor mobility is included with the sediment mobility files. Metadata also include any additional references, such as peer reviewed publications, reports, or Web sites that provide additional information on the models and their parameterizations. These metadata provide users with detailed information on the model and sediment parameters that will be helpful in interpreting the stress and mobility statistics. 


\section{Data Validation}

Quality control (QC) checks are performed as part of model review, and errors are rectified before submission to the database manager for review prior to inclusion in the database.

Procedures for Quality Control.-The following protocols are used to ensure data quality:

- Model data are accessed from Web sites and other data servers in consultation with the principal investigators responsible for model operation to determine the most appropriate model output for stress characterization;

- In cases where model data are not available, the gaps are filled by selecting and implementing an appropriate model over the domain of interest;

- Wave and current model data are validated against field observations as available and appropriate;

- Data processing steps are documented and recorded;

- Stress and mobility statistics are examined for outliers or other artifacts; if found, the statistics and underlying stress time series are reviewed and corrected as necessary.

\section{Data Review}

The stress and mobility data are reviewed prior to inclusion in the database. After stress and mobility calculations are completed, files to be added to the database are reviewed by the database manager. This review verifies that

- metadata are complete and accurate; and

- data format standards are met.

o Before inclusion in the database, statistics are also reviewed and interpreted by project scientists to verify that

- ranges, patterns, and trends are reasonable; and

- data and metadata formats are error-free.

Data are continually assessed as they are used in analysis by USGS and others. If errors or inconsistencies are discovered, then the data in the database are updated and changes documented in the metadata.

\section{Database Access via the Web}

A Sea Floor Stress and Sediment Mobility Database homepage (http://woodshole.er.usgs.gov/project-pages/mobility/) describes the database and the processes used to create it. The database is assembled by geographic regions of the U.S. Continental Shelf that approximately correspond to the U.S. Integrated Ocean Observing System (IOOS) regions (http://www.ioos.gov/). The Sea Floor Stress and Mobility data may be accessed through the USGS Internet map server (http://coastalmap.marine.usgs.gov/regional/contusa/index.html). Estimates of sea floor stress and mobility are being added to the online database as they are developed for each region.

\section{Acknowledgments}

Pat Dickhudt of Integrated Statistics provided recommendations on critical stress thresholds for cohesive beds. 


\section{Selected References}

Churchill, J.H., Wirick, C.D., Flagg, C.N., and Pietrafesa, L.J., 1994, Sediment resuspension over the continental shelf east of the Delmarva Peninsula: Deep Sea Research Part II: Topical Studies in Oceanography, v. 41, nos. 2-3, p. 341-363.

Clauser, F.H., 1956, The turbulent boundary layer: Advances of Applied Mechachics, v. 4, p. 1-51.

Dickhudt, P.J., Friedrichs, C.T., and Sanford, L.P., 2011, Mud matrix solids fraction and bed erodibility in the York River estuary, USA, and other muddy environments: Continental Shelf Research, v. 31, no. 10, supplement, p. S3-S13.

Foreman, M.G.G., 1977, Manual for tidal heights analysis and prediction: Sidney, Canada, Institute of Ocean Sciences, Patricia Bay, Pacific Marine Science Report 77-10, 58 p.

Foreman, M.G.G., 1978, Manual for tidal currents analysis and prediction: Sidney, Canada, Institute of Ocean Sciences, Patricia Bay, Pacific Marine Science Report 78-6, 57 p.

Glenn, S.M., 1983, A continental shelf bottom boundary layer model—The effects of waves, currents, and a moveable bed: Cambridge, Mass., Massachusetts Institute of Technology and Woods Hole Oceanographic Institution Ph.D. dissertation, 237 p.

Glenn, S.M., and Grant, W.D., 1987, A suspended sediment stratification correction for combined wave and current flows: Journal of Geophysical Research, v. 92, no. C8, p. 8244-8264.

Godin, Gabriel, 1972, The analysis of tides: Toronto, Canada, University of Toronto Press.

Goud, M.R., 1987, Prediction of continental shelf sediment transport using a theoretical model of the wave-current boundary layer. Cambridge, Mass., Massachusetts Institute of Technology and Woods Hole Oceanographic Institution Ph.D. dissertation, 211 p.

Grant, W.D., and Madsen, O.S., 1979, Combined wave and current interaction with a rough bottom: Journal of Geophysical Research, v. 84, no. C4, p. 1797-1808.

Grant, W.D., and Madsen, O.S., 1982, Movable bed roughness in unsteady oscillatory flow: Journal of Geophysical Research, v. 87, no. C1, p. 469-481.

Grant, W.D., and Madsen, O.S., 1986, The continental-shelf bottom boundary-layer: Annual Review of Fluid Mechanics, c. 18, p. 265-305.

Hemer, M.A., 2006, The magnitude and frequency of combined flow bed shear stress as a measure of exposure on the Australian continental shelf: Continental Shelf Research, v. 26, no. 11, p. 1258-1280. Holthuijsen, L.H., Booij, N., and Ris, R.C., 1993, A spectral wave model for the coastal zone, in Magoon, O.T., and Hemsley, J.M., eds., Proceedings of the Second International Symposium on Ocean Wave Measurement and Analysis, New Orleans, La., July 25-28, 1993: New York, N.Y., American Society of Civil Engineers, p. 630-641.

Lyne, V.D., Butman, Bradford, and Grant, W.D., 1990a, Sediment movement along the U.S. east coast continental shelf-I. Estimates of bottom stress using the Grant-Madsen model and near-bottom wave and current measurements: Continental Shelf Research, v. 10, p. 397-428.

Lyne, V.D., Butman, Bradford, and Grant, W.D., 1990b, Sediment movement along the U.S. east coast continental shelf-II. Modelling suspended sediment concentration and transport rate during storms: Continental Shelf Research, v. 10, p. 429-460.

Madsen, O.S., 1994, Spectral wave-current bottom boundary layer flows: International Conference on Coastal Engineering, 24th, Kobe, Japan, Octobe 23-28, 1994, proceedings, p. 384-398.

Madsen, O.S., Poon, Ying-Keung, and Graber, H.C., 1988, Spectral wave attenuation by bottom friction-Theory: International Conference on Coastal Engineering, 21st, Coata del Sol-Malaga, Spain, June 20-25, 1988, p. 492-504. 
Madsen, O.S., Wright, L.D., Boon, J.D., and Chisholm, T.A., 1993, Wind stress, bed roughness and sediment suspension on the inner shelf during an extreme storm event: Continental Shelf Research, $\mathrm{v}$. 13, no. 11, p. 1303-1324.

Nikuradse, J., 1933, Strömungsgesetze in rauhen rohren [Laws of turbulent pipe flow in rough pipes]: VDI-Forchlungsheft 361. [Translated in National Advisory Commission for Aeronautics, Technical Memorandum 1292, 1950.]

Panagiotopoulos, I., Voulgaris, G., and Collins, M.B., 1997, The influence of clay on the threshold of movement of fine sandy beds: Coastal Engineering, v. 32, no. 1, p. 19-43.

Pawlowicz, Rich, Beardsley, Bob, and Lentz, Steve, 2002, Classical tidal harmonic analysis including error estimates in MATLAB using T_TIDE: Computers \& Geosciences, v. 28, p. 929-937.

Sanford, T.B., and Lien, Ren-Chieh, 1999, Turbulent properties in a homogeneous tidal bottom boundary layer: Journal of Geophysical Research, v. 104, p. 1245-1257.

Shchepetkin, A.F., and McWilliams, J.C., 2005, The regional oceanic modeling system (ROMS)—A split-explicit, free-surface, topography-following-coordinate oceanic model: Ocean Modelling, v. 9, no. 4, p. 347-404.

Soulsby, Richard, 1997, Dynamics of marine sands-A manual for practical applications: London, Thomas Telford Publications, p.

Torfs, H., Jiang, J., and Mehta, A.J., 2000, Assessment of the erodibility of fine/coarse sediment mixtures: Proceedings in Marine Science, v. 3, p. 109-123.

van Ledden, M., van Kesteren, W.G.M., and Winterwerp, J.C., 2004, A conceptual framework for the erosion behaviour of sand-mud mixtures: Continental Shelf Research, v. 24, no. 1, p. 1-11.

Welch, P.D., 1967, The use of fast fourier transform for the estimation of power spectra-A method based on time averaging over short, modified periodograms: IEEE Transactions on Audio and Electroacoustics, v. 15, p. 70-73.

Zhenlin Li, Michael, 1994, Direct skin friction measurements and stress partitioning over movable sand ripples: Journal of Geophysical Research, v. 99, no. C1, p. 791-799. 


\section{Glossary}

$\delta_{\mathrm{w}}$ Thickness of the wave bottom boundary layer (measured in meters)

Tcr Critical stress threshold (measured in pascals)

$\mathbf{T}_{\text {curr }}$ Current-induced bottom shear stress (measured in pascals)

Twave Wave-induced bottom shear stress (measured in pascals)

Twc Combined wave- and current-induced bottom shear stress (measured in pascals)

$\mathbf{d}_{50}$ Median grain size (measured in meters)

$\mathbf{k}_{\mathbf{b}}$ Bottom roughness defined as Nikuradse sand grain size (measured in meters)

$\mathbf{T}_{\mathrm{br}} \quad$ Representative bottom wave period (measured in seconds)

$\mathbf{u}_{\mathrm{br}}$ Representative bottom orbital velocity (measured in meters per second)

WBL Wave bottom boundary layer (measured in meters)

$\mathbf{Z}_{\mathbf{R}}$ Current reference height (measured in meters) 
For more information concerning this report, contact

Director

U.S. Geological Survey

Woods Hole Coastal and Marine Science Center

384 Woods Hole Road

Quissett Campus

Woods Hole, MA 02543-1598

WHSC_science_director@usgs.gov

508-548-8700 or 508-457-2200

or visit our Web site at

http://woodshole.er.usgs.gov 
